\title{
Butterflies in Swedish grasslands benefit from forest and respond to landscape composition at different spatial scales
}

\author{
Karl-Olof Bergman (D) Juliana Dániel-Ferreira • Per Milberg • \\ Erik Öckinger · Lars Westerberg
}

Received: 4 February 2018/ Accepted: 20 October 2018/Published online: 13 November 2018

(C) The Author(s) 2018

\begin{abstract}
Context Loss and fragmentation of semi-natural grasslands has critically affected many butterfly species in Europe. Habitat area and isolation can have strong effects on the local biodiversity but species may also be strongly affected by the surrounding matrix.

Objectives We explored how different land cover types in the landscape explained the occurrence of butterfly species in semi-natural grasslands.

Methods Using data from 476 semi-natural grasslands in Sweden, we analysed the effect of matrix composition on species richness and occurrence. Additionally, we analysed at which spatial scales butterflies responded to matrix types (forests, seminatural grasslands, arable land and water).

Results Forest cover showed the strongest positive effect on species richness, followed by semi-natural grasslands. Forest also had a positive effect on red-
\end{abstract}

Electronic supplementary material The online version of this article (https://doi.org/10.1007/s10980-018-0732-y) contains supplementary material, which is available to authorized users.

K.-O. Bergman $(\bowtie) \cdot J$ J Dániel-Ferreira ·

P. Milberg · L. Westerberg

IFM Biology, Conservation Ecology Group, Linköping

University, 58183 Linköping, Sweden

e-mail: karl-olof.bergman@liu.se

J. Dániel-Ferreira $\cdot$ E. Öckinger

Department of Ecology, Swedish University of

Agricultural Sciences, Box 7044, 75007 Uppsala, Sweden listed species at local scales. Responses to matrix composition were highly species-specific. The majority of the 30 most common species showed strong positive responses to the amount of forest cover within 200-500 m. There was a smaller group of species showing a positive response to arable land cover within 500-2000 m. Thirteen species showed positive responses to the amount of semi-natural grasslands, generally at larger scales (10-30 km).

Conclusions Our study showed that surrounding forest is beneficial for many grassland butterfly species and that forests might mitigate the negative effects of habitat loss caused by agricultural intensification. Also, semi-natural grasslands were an important factor for species richness at larger spatial scales, indicating that a landscape consisting mainly of supporting habitats (i.e. forests) are insufficient to sustain a rich butterfly fauna.

Keywords Conservation - Forest - Grassland . Landscape composition - Lepidoptera $\cdot$ Spatial scale

\section{Introduction}

Intensified land use has led to significant declines in global biodiversity through the loss, modification and fragmentation of habitats (Foley et al. 2005; Barnosky et al. 2012). In Europe, semi-natural grasslands, i.e. grasslands that has not been affected by cultivation, 
inorganic fertilizers or herbicides and maintained by traditional management as mowing or grazing, are among the most species-rich habitats. However, their area has dramatically been reduced due to agricultural intensification or land abandonment (WallisDeVries et al. 2002; Tscharntke et al. 2005; Stoate et al. 2009; Cousins et al. 2015). The loss and fragmentation of semi-natural grasslands has critically affected many butterfly species, with a $30 \%$ decrease of grassland butterfly abundance between 1990 and 2013 (van Swaay et al. 2013). The effects of habitat loss have been particularly detrimental for specialist butterfly species, which have had more severe distribution declines than generalist species (van Swaay et al. 2006).

Because many species persist in habitat patches in fragmented landscapes, the theories of island biogeography (MacArthur and Wilson 1967) and metapopulation dynamics (Levins 1969; Hanski 1999) have provided theoretical frameworks for conservation efforts. The remaining habitat patches have been considered analogous with oceanic islands and the surrounding matrix analogous to the sea, assuming that the landscape consists of suitable habitat patches embedded in an inhospitable matrix (Ricketts 2001). However, even though habitat area and isolation have been shown to have strong effects on the local biodiversity (Fahrig 2003; Ewers and Didham 2005; Tscharntke et al. 2005; Öckinger and Smith 2006; Botham et al. 2015; Duflot et al. 2015), a substantial body of research also shows that species abundance and composition in remaining habitat patches are strongly affected by the surrounding matrix (Ricketts 2001; Prevedello and Vieira 2010; Watling et al. 2011; Evans et al. 2017).

The matrix influences species' occurrence and spatial dynamics through effects associated with dispersal, resource availability and the abiotic environment (Driscoll et al. 2013) and the matrix effects are strongly species-specific (Prevedello and Vieira 2010). Depending on the species' resource requirements and dispersal ability, certain types of land cover may either represent barriers with different degrees of permeability or a set of complementary resources (Ouin et al. 2004; Öckinger et al. 2012a). Therefore, the matrix composition affects the sensitivity of species to patch area and isolation (Prugh et al. 2008). For example, Öckinger et al. (2012b) found that the negative effect of small patch size for butterflies was stronger in patches embedded in landscapes dominated by arable land than in forest dominated landscapes. Thus, landscape structure (habitat amount and distribution) and matrix quality have important effects on biodiversity. However, their relative importance may also be scale-dependent (Smith et al. 2011). The processes that influence species distributions act on different spatial scales. For successful conservation, it is important to understand how and why species differ in their response to landscape structure (Shreeve and Dennis 2011). Such differences have been attributed to life history traits (Ewers and Didham 2005; Prugh et al. 2008; Öckinger et al. 2010; Halder et al. 2017), e.g. species with low reproduction, low dispersal ability and specialist host plant requirements have been shown to be most sensitive to habitat loss (Öckinger et al. 2010). Species traits have also been linked to different matrix response for many species groups, from plants to birds (Davies et al. 2000; Dupré and Ehrlén 2002; Pöyry et al. 2009; Kennedy et al. 2010). Strategies aimed to mitigate and counteract the negative effects of agricultural intensification on biodiversity have been implemented in several countries across Europe since the 1970s, but the problems still faced by conservationists and policy makers are to understand how species respond to habitat changes, where to target conservation and how large areas that should be protected (Franklin 1993; Green et al. 2005; Broughton et al. 2014; Botham et al. 2015).

Using data from an ongoing national monitoring program of butterflies in Sweden, this study aims to answer the following questions: (1) How do matrix composition influence the occurrence of butterfly species in semi-natural grasslands? Can different land cover types in the landscape (semi-natural grasslands, arable land, forests, and water surfaces) explain the occurrence of butterfly species in semi-natural grasslands? (2) At which spatial scale do butterflies respond to different matrix types surrounding the semi-natural grasslands? (3) Can life history traits explain the spatial scale of response? More specifically, we expected (i) a positive relationship between species' wing span and scales of response as individuals with larger wings can potentially disperse longer, (ii) a negative relationship between time for larval development and scales of response because fast development has been suggested to be associated to frequent habitat disturbance and high dispersal ability (Börschig et al. 2013), and (iii) a positive relationship 
with a wider use of host plants as there would be more suitable habitat available for those being generalist feeders.

\section{Materials and methods}

Study area

The study area encompassed the southern part of Sweden, excluding the islands of Öland and Gotland $\left(\sim 158000 \mathrm{~km}^{2}\right)$. There are large regional differences in land use in the area, from regions almost totally dominated by forest to intense agricultural areas, including large differences in the density of semi-natural grasslands (Fig. 1). The most abundant land cover type was forest ( $\sim 62 \%$ of the total area), followed by arable land $(\sim 16 \%)$ and water $(\sim 12 \%)$. Semi-natural grasslands were the most

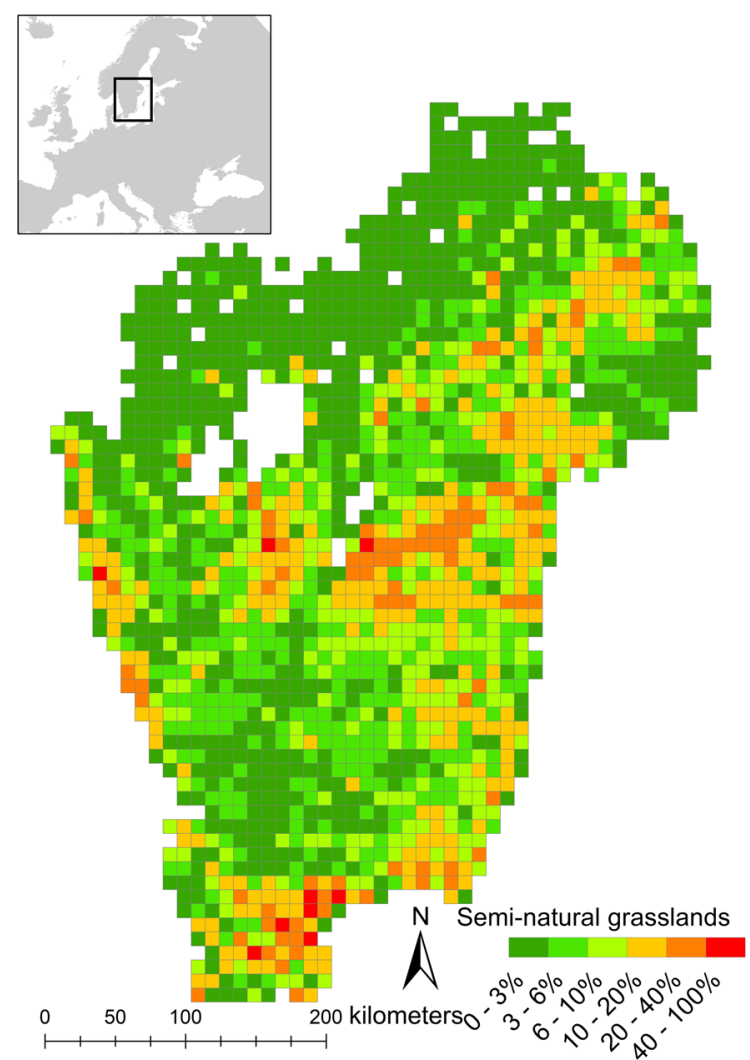

Fig. 1 Total area of semi-natural grasslands of high conservation value in $100 \mathrm{~km}^{2}$ squares in southern Sweden according to the Swedish Natural Survey of semi-natural meadows and pastures (TUVA). White areas indicate water scarce land cover type, with only $\sim 1.2 \%$ of the total studied area.

Butterfly data and life history traits

We used butterfly data from the National Inventory of Landscapes in Sweden (NILS, Ståhl et al. 2011). NILS is a nation-wide monitoring program which aims to monitor biodiversity and land use changes over time in the entire landscape. In order to do so, 600 NILS sites $(5 \times 5 \mathrm{~km}$ squares $)$ are systematically placed throughout the country, which has been divided in 10 geographical strata. Since 2006, NILS also surveys biodiversity in 696 randomly selected semi-natural grasslands located within the 600 NILS sites. The sites are surveyed with a 5 years monitoring interval, with $20 \%$ of the sites visited per year (Ståhl et al. 2011). Butterfly abundance is affected by the weather, and it is likely that the weather also affects the abundances between the 5 years in the present study. However, as our sampling was spatially randomly distributed between years, we expect that these differences affected different sites in a similar way, i.e. sites with high species richness and abundance are affected in the way as sites with low species richness and abundance. This will give the same patterns in our analyses, although the patterns may be weaker.

Every fifth year the butterfly recordings are performed three times in each grassland between May and September using the transect-line method (Cronvall 2015). Here, we consider data collected 2006-2010, i.e. data from 1 year for each of the visited sites. Recorded species include members of the families Papilionoidea, Hesperioidea, Zygaenidae and the two day-flying species of Sphingidae, Hemaris tityus and H. fuciformis. For simplicity, these groups will be referred to as "butterflies"' throughout this paper. Two pairs of butterfly species, Plebeius argus/P. idas and Leptidea juvernica/L. sinapis, were pooled since they are difficult to identify in the field. Three environmental variables measured during the surveys; area of the grassland, vegetation height and flower richness, were also included in the study to control for local environmental variables. Vegetation height was classified into three height classes $(<5 \mathrm{~cm}, 5-15 \mathrm{~cm}$ and $>15 \mathrm{~cm}$ ) in the field and measured as the percentage of the area along a given transect covered by each class. Flower richness refers to the average of coverage of nectar bearing flowers in the sites, and was 
assessed in parts per thousand (\%o). The surveyor was instructed to "divide" the transect into relatively homogeneous segments and subsequently estimate the flower cover in each segment. The flower richness of the transect was then a result of an average between all the segments in the transect. The length of the transects ( $\mathrm{y} \mathrm{m}$ ) depended on the sizes of the grassland $\left(\mathrm{x} \mathrm{m}^{2}\right)$ and follows a logarithmic function, $y=267.31 * \ln (x)-1974\left(R^{2}=0.90\right)$. Mean transect length was $833.1 \mathrm{~m}$ (range 42.5-2203.5), mean site area was 3.6 ha (range 0.08-98.1). The transect width was always $10 \mathrm{~m}$.

Given the climatic and geographic differences between southern and northern Sweden and the distribution of the majority of the butterfly species studied, we performed analyses using only the southern sites in stratum 1-6 in NILS (Fig. 2a). We also decided to exclude the sites present at the islands of Öland and Gotland from the analyses because of their distinctive geology with large areas of shallow soils on limestone, resulting in distinctive landscape composition and landscape history that may confuse the results for the mainland (Fig. 2a). This process yielded a total of 476 semi-natural grasslands (hereafter "sites") that were used in this study. In the species-wise analyses, we included only sites within a species' geographic distribution range, this being defined according to Eliasson (2005). For species not included in Eliasson (2005), i.e. species of the families Zygaenidae, Sphingidae and for the sister species $L$. juvernical sinapis, we used data from the Species Reporting System (ArtPortalen, https://www.artportalen.se [Access date: 2015-10-16]), to create distribution maps by setting a $20 \mathrm{~km}$ radius around each reported finding during the time period 1900-2015. For each species, the sites that did not overlap with the distribution range were removed from the analysis. The nomenclature follows the Swedish Species Information Centre taxonomic database Dyntaxa (http://www.slu.se/dyntaxa/ ).

Data on three life history traits for the butterflies (excluding species of the families Zygaenidae and Sphingidae) were obtained from Bink (1992): (1) wing length (mean in $\mathrm{mm}$ ), (2) time as larva (number of days larva are active and feeding), (3) diet [specialization of larva in three categories, monophagous (1-2 plant genera within one plant family), oligophagous (many genera within one plant family), polyphagous (several plant families)].
Land use data

The amount of semi-natural grasslands, arable land, forests and water were measured in 34 concentric circles ranging from $100 \mathrm{~m}$ to $40 \mathrm{~km}$ radius (scale) around each selected focal grassland (Fig. 2b). We used the database of the Swedish national survey of semi-natural meadows and pastures (TUVA, http:// www.jordbruksverket.se/tuva [Access date 2013-0924]) to extract the area of semi-natural grasslands (habitat amount cover) for each scale. The grasslands included in the database are classified as of high nature value (Swedish Board of Agriculture 2005) and consist of managed (grazed or mowed) semi-natural pastures and meadows, and "grasslands possible to restore" (recently abandoned semi-natural grasslands). The database contained one more class, "not applicable", that were excluded in the present study. These grasslands were identified as valuable grasslands at earlier surveys but were at the latest survey found to be of low quality, for example due to abandonment, forest plantations or fertilization.

To measure matrix composition around the seminatural grassland sites, the SMD Swedish Land Cover database (a Swedish version of the CORINE land cover database) was used to extract the amount of forests (coniferous, deciduous, mixed and young forest and clear-cuts pooled together), arable land and water surfaces that surround the surveyed seminatural areas in each scale (Environmental Protection Agency 2014) downloaded from: http://gis-services. metria.se/nvfeed/atom/annex 2.xml [Access date 2015-05-12]. All land cover calculations and maps were performed in ArcMap 10.1 (ESRI 2012). Other types of land cover, such as artificial surfaces or wetlands were not used in the study.

In order to avoid the spatial autocorrelation that emerges from shared land cover composition for sites situated close to each other, we used the program Focus 2.1 (Holland et al. 2004) to extract 100 possible site combinations (out of 1000 iterations) for each scale that yielded non-overlapping sites. This resulted in a different number of sites for each scale, where the mean number of sites was 473 for the smallest scale $(100 \mathrm{~m})$ and 54.3 for the largest scale $(40 \mathrm{~km})$.

We found a significant positive correlation between the amount of semi-natural grasslands and the amount of arable land at the scale of $631 \mathrm{~m}$ and higher (highest Pearson's $r=0.49, \mathrm{p}=0.0002$ at the $40 \mathrm{~km}$ scale). 


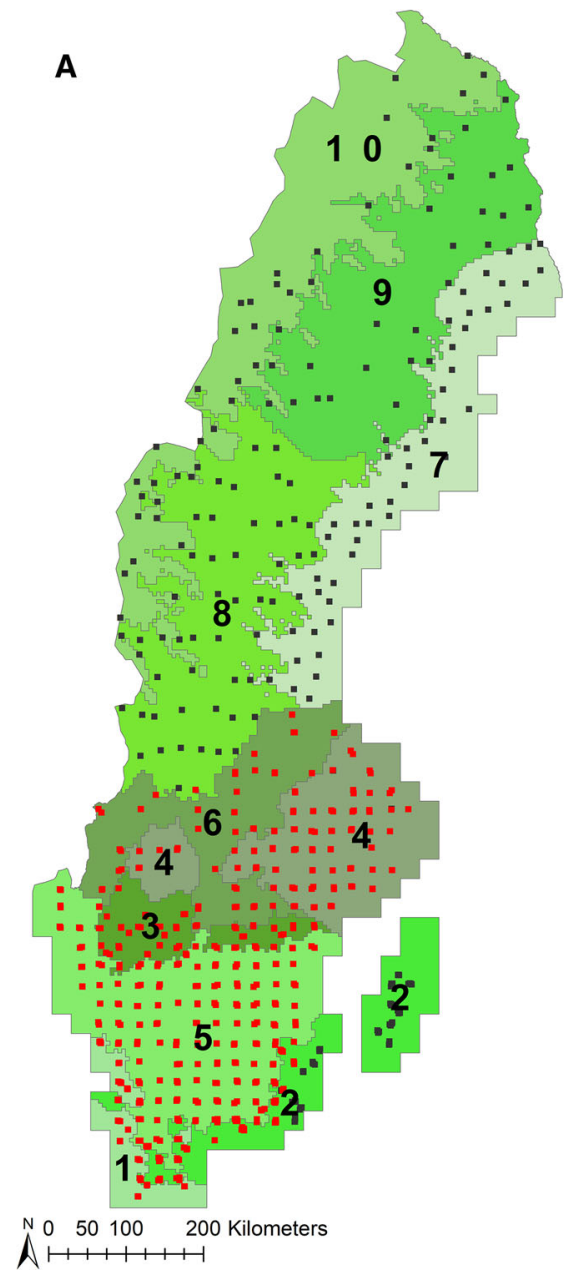

Fig. 2 a Map showing the location of the 696 semi-natural grasslands where butterfly diversity is surveyed by NILS. A dot represents the location of one or more semi-natural grasslands and the red dots represent the sites selected for this study. The map also shows the 10 geographical strata in which Sweden is

There was also a small negative correlation between the amount of semi-natural grasslands and the amount of forest cover at the smaller to medium scales (from $100 \mathrm{~m}$ to $\sim 3 \mathrm{~km})$ (Fig. 3).

The variation in cover of land use classes, expressed as coefficient of variation $(\mathrm{CV})$, varied both among classes and scales. On average over scales, water displayed the largest CV (190\%), arable land and semi-natural grassland intermediate $(94 \%$ and $90 \%)$, and forest the smallest (61\%).
B

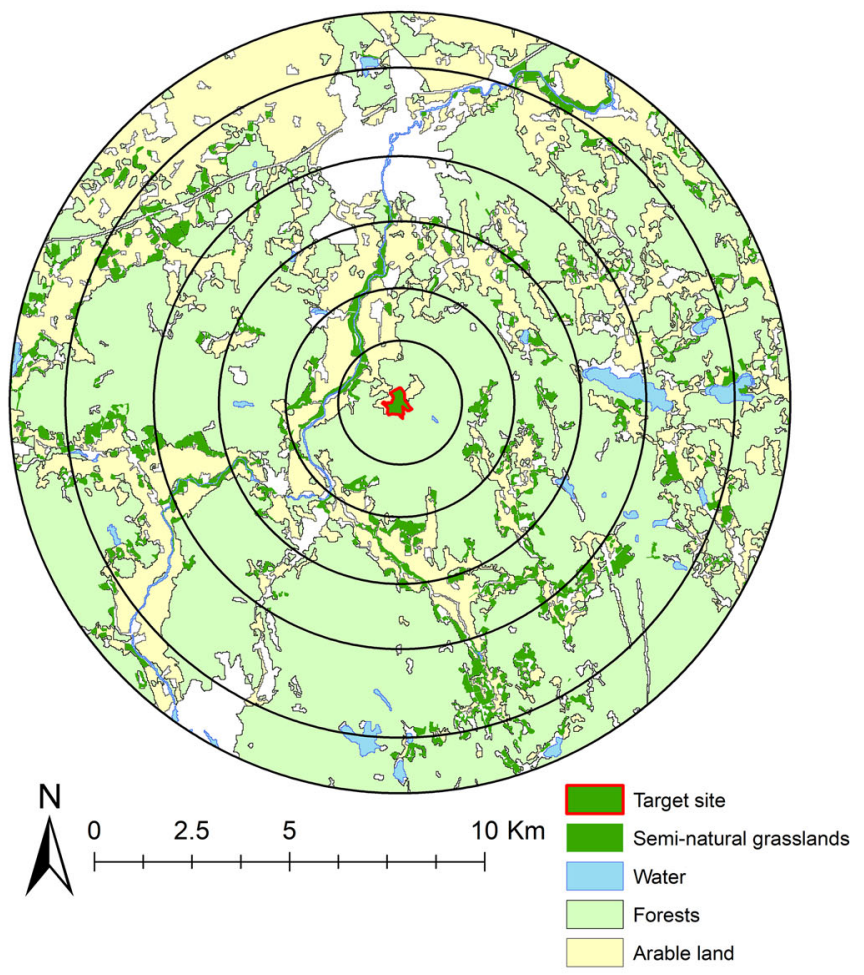

divided. b The amount of forests, arable land, grasslands and water cover was measured in 34 circles around the focal site (a smaller amount of scales is shown in the figure for simplicity). The white areas represent different types of land cover that were not used in this study

\section{Analyses}

The statistical analyses were performed in $\mathrm{R}(\mathrm{R}$ Development Core Team 2014) except the analysis of life history traits. The response of species richness was modeled as an additive effect of the amount of seminatural grasslands, arable land, forests and water (and covariates, see below) around the 476 sites for each of the 34 radii and was tested with a negative binomial generalized linear model. In the species-wise analyses, four separate binomial generalized linear models (logit-link), one for each land cover type, were fitted to estimate the odds of finding a specific species in a 


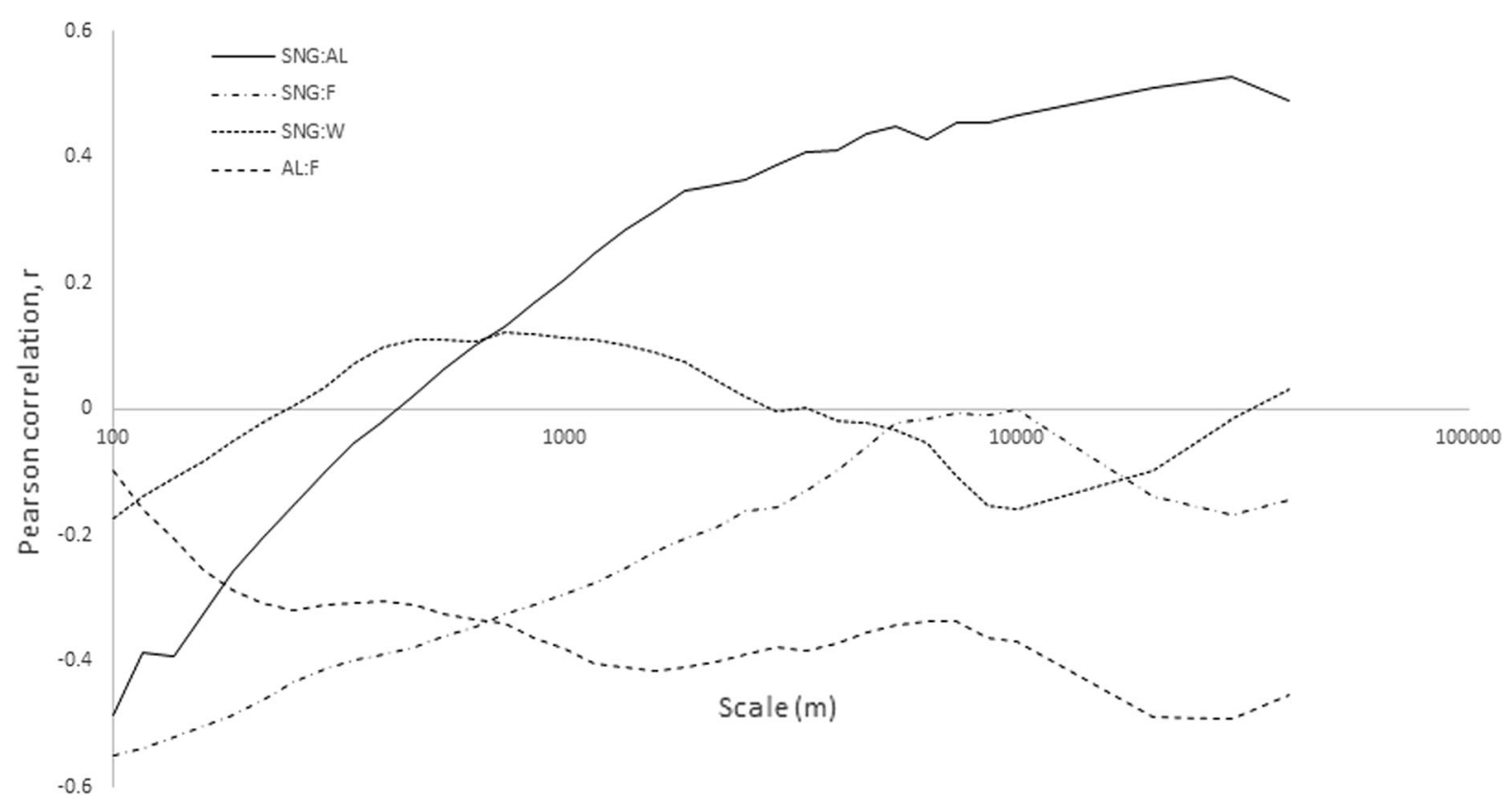

Fig. 3 Pearson correlation coefficients (r) for each scale between semi-natural grasslands (SNG) and arable land (AL), forests (F) and water surfaces $(\mathrm{W})$

site based on the proportion of each land cover type (and covariates, see below) at each spatial scale. The same model was used to estimate the odds of finding one or more red-listed species. The median $z$ value (100 iterations with different site combinations) was used as a test statistic in order to remove any influence of extreme values of $z$. The largest absolute value of median $z$ indicated the scale at which each land cover type explained most of the variation in the odds of finding an individual of a species (called scale of response).

To control for local habitat quality, three covariables available directly from NILS data; vegetation height, grassland area and flower richness, were included in all the models. These variables are known to affect butterfly abundances and occurrences (e.g. Steffan-Dewenter and Tscharntke 2000; Kruess and Tscharntke 2002; Sjödin 2007). All three variables had a positive effect on species richness in this study and the relationships for vegetation height and flower richness for the current data has been reported elsewhere (Milberg et al. 2016).

In order to control for transects of different length, the three vegetation heights were transformed and weighted into one single value per site. In order to do this, the range of each category were re-coded into a single value: $<5 \mathrm{~cm}$ to $2.5 \mathrm{~cm}, 5-15 \mathrm{~cm}$ to $10 \mathrm{~cm}$, and $>15$ to $25 \mathrm{~cm}$. These values were then multiplied by the total number of meters in each transect that belonged to each category. Then, the transect-wise values were weighted by the total transect length of the site so that longer transects had more impact on the final value. Finally, the weighted values were summarized into a mean of vegetation height for each site. The flower richness per site was weighted in a similar way in order to achieve a single mean value per site. The area of forest, arable land and semi-natural grasslands surrounding each site was log-transformed and the area of the site was square-root transformed given the high variability in the size of the habitat patches.

To evaluate if the scale of response was influenced by species' life history traits-wing length, time as larva and diet-we conducted three separate generalized linear models (GLM, normal distribution and identity link) using Statistica 10.0 (Statsoft, Inc., Tulsa, USA). In these analyses, the scale of response chosen for a species was the scale that had the maximum sum of the absolute median $\mathrm{z}$ values for all four land use classes. 


\section{Results}

A total of 32,022 individuals belonging to 77 species of butterflies were recorded. The number of species recorded per site varied between zero and 37 and varied across the landscape (Fig. 4). The number of individuals per site varied between zero and 376 . The most abundant species were Aphantopus hyperantus
(26.4\% of all individuals), followed by Maniola jurtina (11.1\%) and Pieris napi (10.5\%).

Effect of different land cover types on species richness and red-listed species

There was a clear significant positive effect of forest matrix on species richness over the majority of scales
Fig. 4 Number of butterfly species recorded per site in the 476 sites in southern Sweden. If two or more sites are too close together, the site with higher species richness is shown on the top

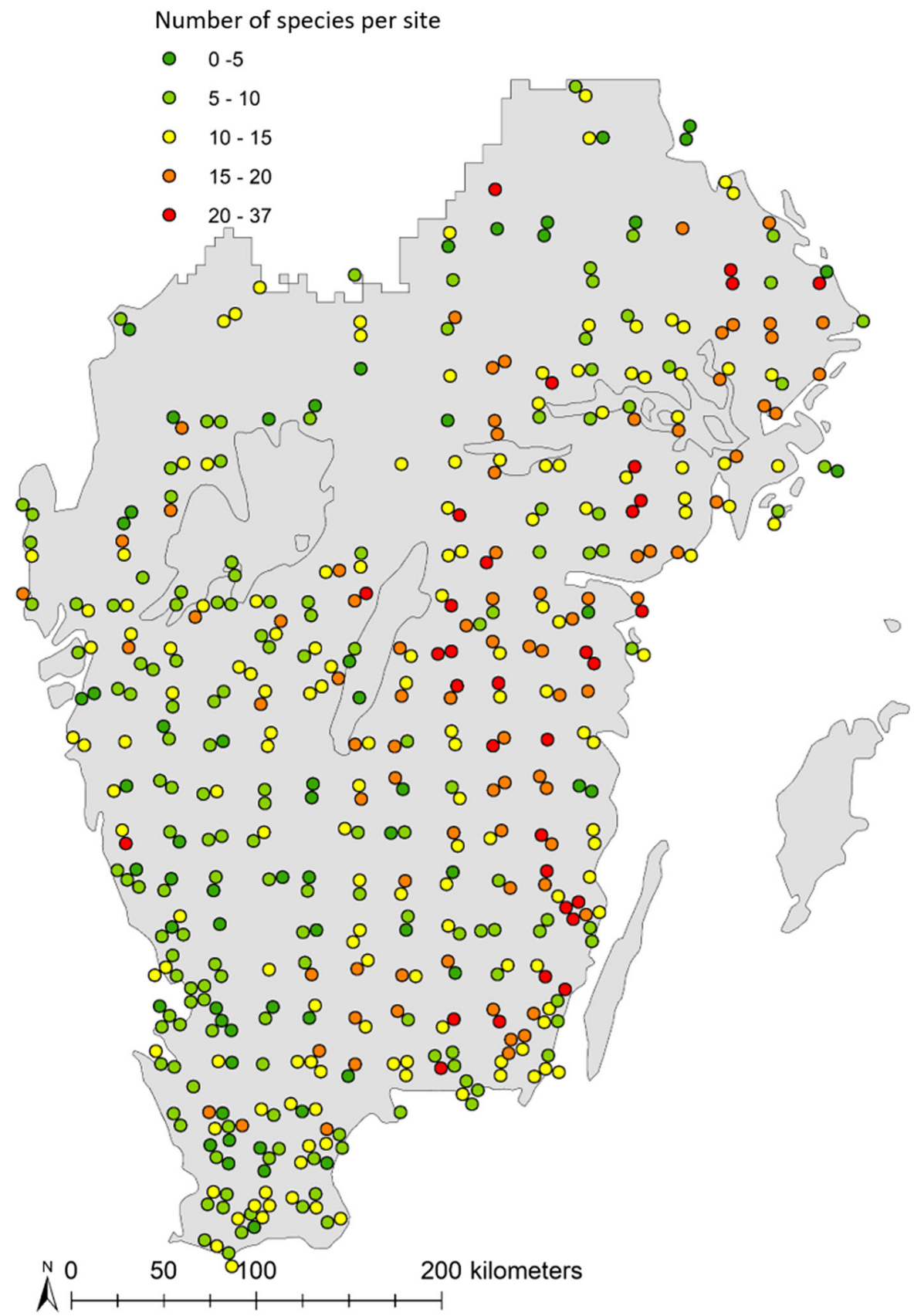


except the smallest and the largest (Fig. 5a). The cover of semi-natural grasslands in the landscape also had a significant positive effect on species richness with the highest peaks for the largest scales above $4500 \mathrm{~m}$ and for local scales. The cover of water had a significant negative effect on species richness on scales below $1500 \mathrm{~m}$ while arable land had no significant effect. The odds of finding a red-listed species was positively related to forest cover on the local scales (Fig. 5b).
The cover of arable land had a negative effect on several of scales smaller than $1200 \mathrm{~m}$. To give an indication of the results of the model we calculated the effect of increasing the value of the median area of respective land cover type with $10 \%$ at peak scale on the species richness. For forest the peak scale was at $341 \mathrm{~m}$ and the effect on species richness was an increase with 0.43 species, seminatural grasslands peaked at $20000 \mathrm{~m}$ and gave an increase with 1.46
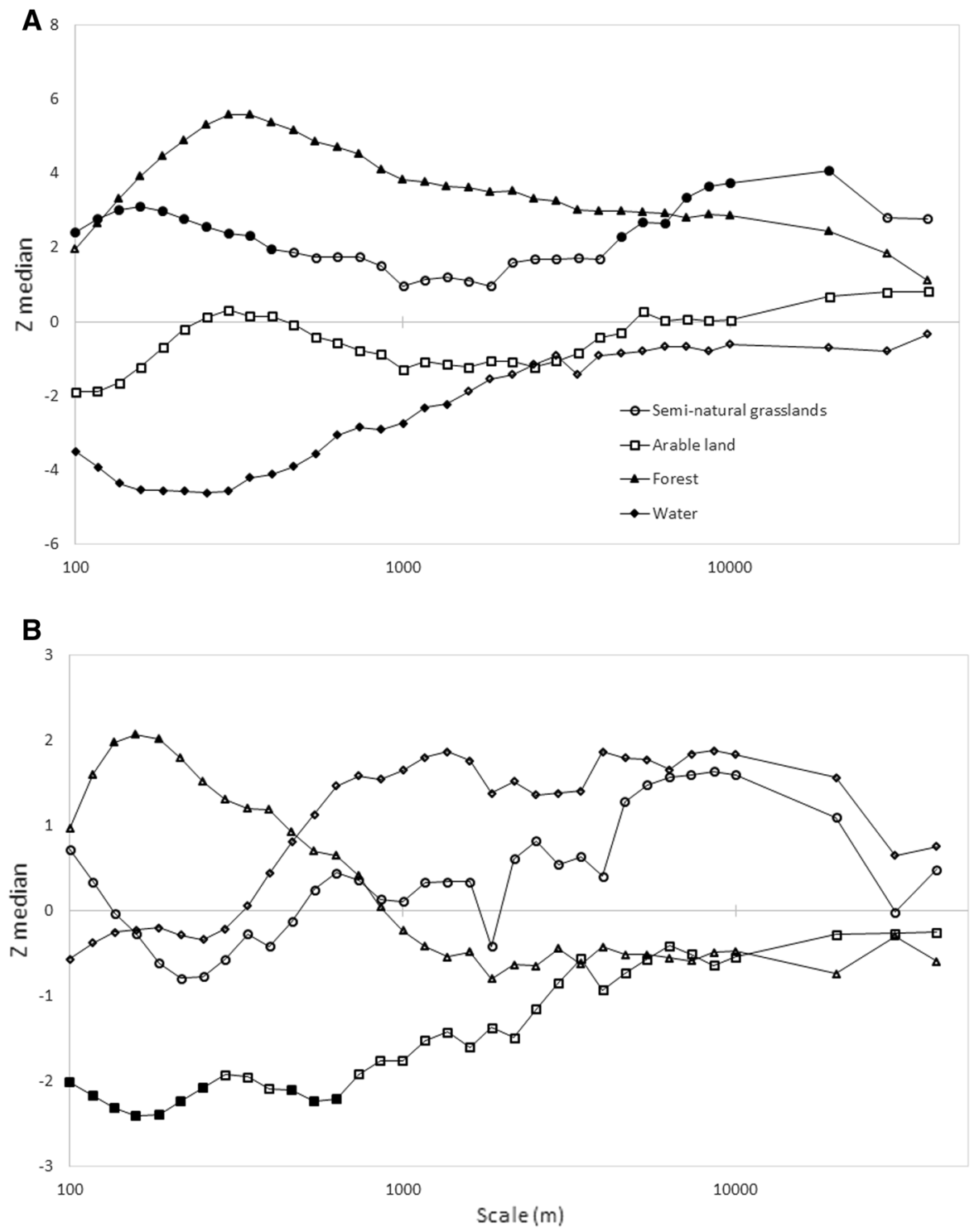

Fig. 5 a Median $\mathrm{z}$ values for species richness as a response to the amount different land cover types in 34 scales around the focal site. b Median $\mathrm{z}$ values for the odds of observing red-listed species as a response to the amount different land cover types in
34 scales around the focal site. The filled shapes represent a statistically significant value of $\mathrm{z}\left(\mathrm{p}<0.05^{*}\right)$. Maximum scale is $40 \mathrm{~km}$ 
species, arable at $117 \mathrm{~m}$ and a decrease with 0.01 species (water peaked at $251 \mathrm{~m}$ but the median area was zero, hence no results were calculated).

Effect of different cover types on individual species and scale of response

Many of the 77 species were rare and yielded no or weak models, hence we present only detailed results from the 30 most common species. The occurrence of the majority of these showed strong positive relationships with the amount of forest cover in the landscape (Fig. 6a), among them many of the fritillaries (Argynnis spp., Boloria spp.). However, one-third of the species analysed showed a negative relationship. These species-dominated by the family Pieridaeinstead often showed a positive response to arable land cover (Fig. 6c). Some species, i.e., Coenonympha arcania and Aphantopus hyperantus, responded positively to the cover of both forest and arable land. Thirteen species showed a positive response to the amount of semi-natural grasslands (Fig. 6b). There is some overlap with species showing positive responses to arable land. However, species like Maniola jurtina and Lycaena phlaeas showed a strong positive response to semi-natural grasslands and weak or negative responses to other land cover types. As expected, water cover had a general negative influence on individual species occurrence (Fig. 6d).

The scale of response was highly species-specific, with species responding from local to landscape scales (Fig. 6a-d). The scales of response to forest cover for individual species were dominated by local scales around $200-500 \mathrm{~m}$ but stretched up to 20 and $30 \mathrm{~km}$. The species responding positively to arable land in general showed a response at mid-range scales, 500-2000 m. The scale of response to semi-natural grasslands showed that several species responded at larger landscape scales (10-30 km), while some species responded at both local and landscape scales.

The scale of response was positively related to only one trait-diet-where oligophagous species had larger and polyphagous smaller scales of response than monophagous (Table 1).

\section{Discussion}

Importance of different land cover types

\section{Butterfly richness}

As expected, the species richness of butterflies in grasslands was positively related to the cover of seminatural grasslands in the surrounding landscape, in line with numerous European studies (e.g. Bergman et al. 2004; Öckinger and Smith 2006; Brückmann et al. 2010). In addition, we found that the occurrence of many butterflies in semi-natural grasslands increased with increasing forest cover in the surrounding landscape. Even though we cannot completely exclude the possibility that the local habitat quality of seminatural pastures is landscape-dependent, such a positive effect of surrounding forests seem to persist across European landscapes (Italy: Marini et al. 2009; Germany: Krämer et al. 2012; Estonia: Liivamägi et al. 2014; France: Villemey et al. 2015; Finland: Toivonen et al. 2017). More indirect evidence for the importance of forests are given by studies showing that the negative effect of habitat fragmentation on butterflies in semi-natural grasslands decreases as the matrix become more dominated by forests (Bergman et al. 2004, 2008; Öckinger et al. 2012b). The explanation for the positive effect of forest cover is that open areas in the forest, such as clear-cuts, powerline corridors, glades and bogs, may serve as alternative habitats for grassland butterfly species (e.g. Marini et al. 2009; Jonason et al. 2010; Ibbe et al. 2011; van Halder et al. 2011; Berg et al. 2016; Viljur and Teder 2016; Lampinen et al. 2018). This is a reasonable assumption, as vegetation in clear-cuts can be rich in both nectar and host plants (Ibbe et al. 2011, Jonason et al. 2014, 2016). In fact, the butterfly density and richness in open habitats in the forest landscape can be at least as high as that in grazed semi-natural grasslands (Berg et al. 2011), an observation that suggest that clear-cuts, given their great total area, could be considered a main habitat today for many of the species normally associated with grasslands (Blixt et al. 2015; Viljur and Teder 2018).

It is worth noting that the positive value of forest on butterflies may not be persistent over time. Jonason et al. $(2014,2016)$ showed that plant species richness in clear-cuts was related to historical land use in the $1800 \mathrm{~s}$ and the introduction of modern forest 
Fig. 6 Characteristic scale of response to the amount of $\mathbf{a}$ forest $\mathbf{b}$ semi-natural grasslands, $\mathbf{c}$ arable land and d water surfaces for the 30 most common species. a For visualization purposes, the species with the most significant positive responses to semi-natural grasslands are located at the top, whilst the species with the most significant negative response are located at the bottom. Graphs b, c and d follow the same order as graph (a). Grey represents a negative response and black a positive response. The size of the circles corresponds in a continuous scale to the explanatory power of the model (z median) and solid circles indicate a significant response $(\mathrm{p}<0.05$ and size 1.96)
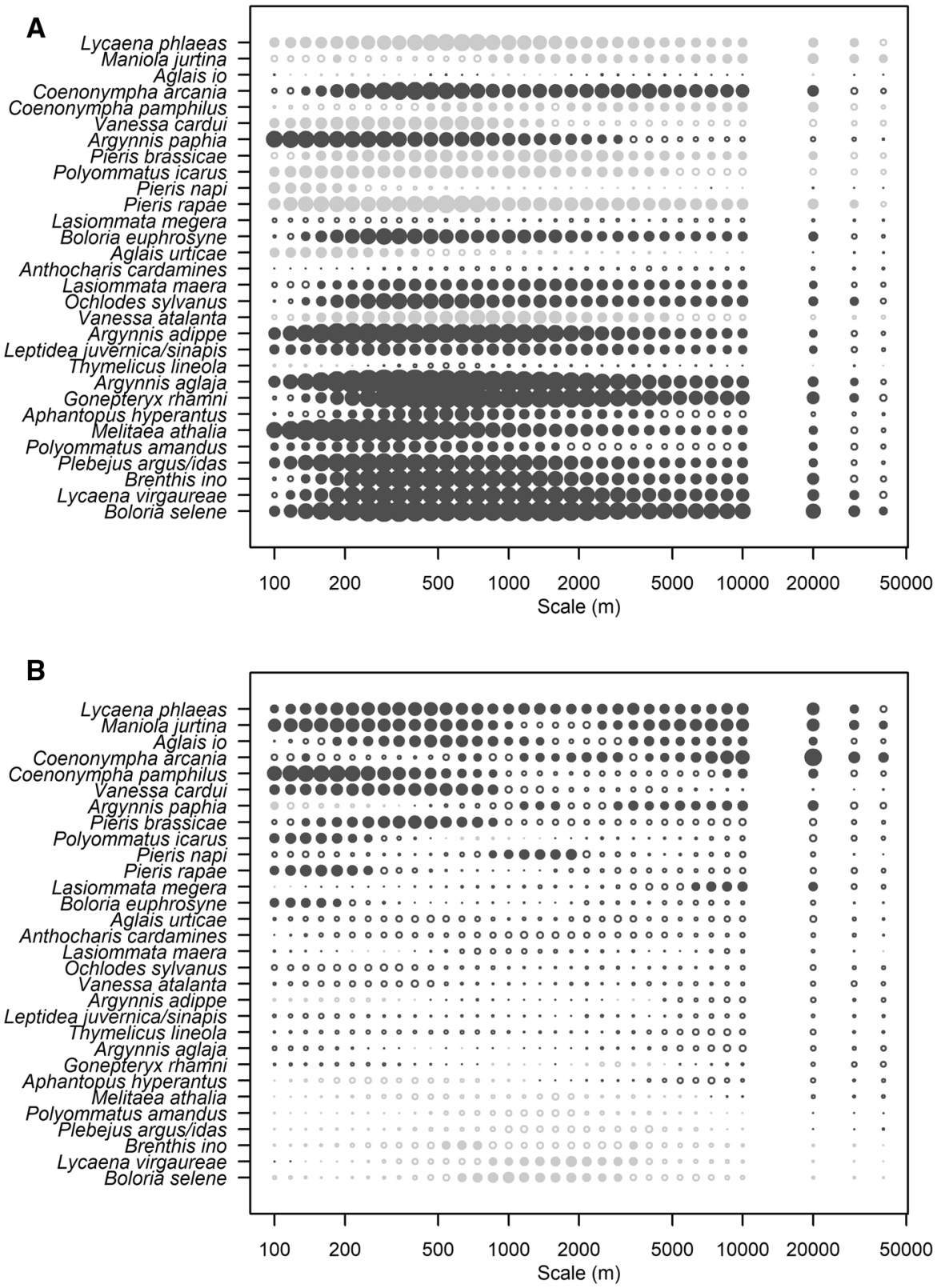

management practices will create more uniform, evenaged, dense and dark stands hostile to grassland plants (Niklasson and Granström 2000; Axelsson and Östlund 2001; Bergstedt et al. 2017). Hence, we expect that future forests will contain fewer open areas, and clear-cuts will become less rich in plants useful for butterflies.
Species- and group-wise patterns

Forest was of great importance to the occurrence of many species in our study, confirming that many species classified as grassland butterflies benefit from forest matrix (Krämer et al. 2012; Öckinger et al. 2012a, b; Villemey et al. 2015; Toivonen et al. 2017). The implication is that that open patches in forests is an important alternative habitat for some of the grassland species. Our study point out, e.g., Argynnis 
Fig. 6 continued
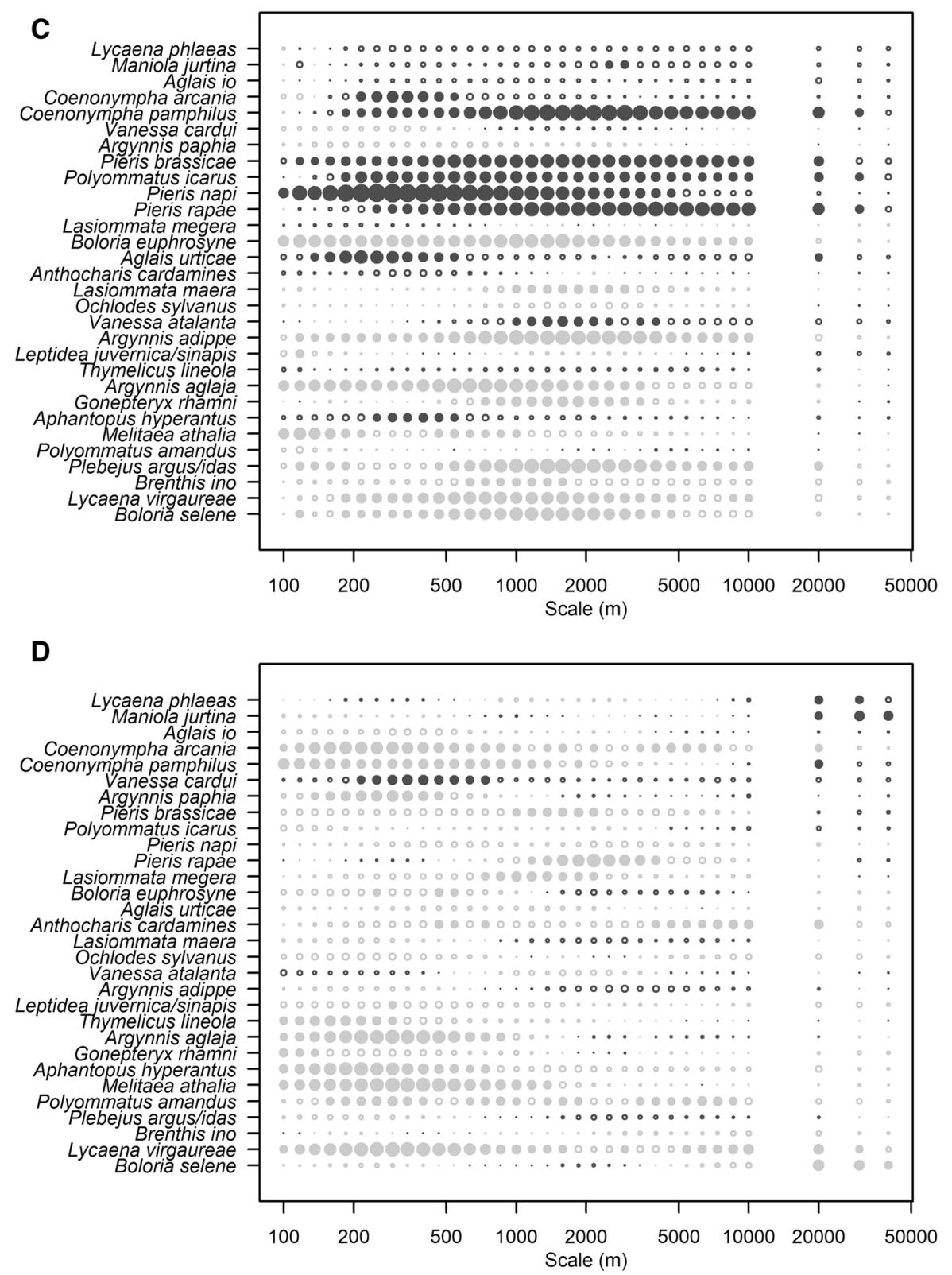

adippe, A. aglaja, Boloria selene, Brenthis ino and Lycaena virgaureae.

Maybe the most surprising results were the generally weak effect of surrounding grasslands on butterflies recorded in grasslands, and that several species classified as grassland species in other studies (Van Swaay et al. 2006; Kuussaari et al. 2007; Krauss et al. 2010) did not show a general positive response to the amount of semi-natural grasslands in the landscape. It should be noted though, that semi-natural grasslands make up a small part of the Swedish landscape (1.2\% in our study area), so for species that can exploit openings in forests, a positive effect of grasslands may not be detectable. For such species, one might also question their classification as grassland species, and what their main habitat actually is.

The species that showed a strong positive response to arable fields are all but one classified as generalists or migratory species by Komonen et al. (2004). Some of them, e.g. Pieris spp., feed on crops or weeds, so 
Table 1 The effect of three life history traits on the scale of response (ln-transformed) of species

\begin{tabular}{lllll}
\hline & $\mathrm{N}$ & Estimate & $95 \%$ confidence interval & Wald \\
\hline Wing length & 30 & -0.23 & $-0.80 ; 0.34$ & 0.62 \\
Time as larva & 29 & -0.071 & $-0.214 ; 0.072$ & 0.95 \\
Diet & 30 & $0.87(\mathrm{o})$ & $0.46 ; 1.28$ & $16.9 *$ \\
& & $-0.416(\mathrm{p})$ & $-0.791 ;-0.041$ & \\
\hline
\end{tabular}

Three separate models (GLZ) were run, one for each trait

The explanatory variables wing length and time as larva were square root transformed. $* \mathrm{p}<0.05 . o$ oligophagous (several genera within a plant family), and $p$ polyphagous (several families) which were contrasted against monophagous (1-2 genera within a family)

their results were expected. Several species responded negatively to arable land, a pattern expected among specialists and less mobile species (Ekroos et al. 2010). This may, in fact, explain the negative response of several species to semi-natural grasslands as there was a positive correlation between arable land and semi-natural grassland. This is an expected relationship as farms specialising in cattle or dairy production in our study area also operate arable fields.

\section{Scale of effect}

In the current study, based on a national monitoring system, we were able to use larger scales than in most other studies (that normally test scales below $5000 \mathrm{~m}$ ) and we focused on two land cover types of particular interest for the grassland assemblages of butterflies sampled: semi-natural grassland and forest. We found that the clear positive effect of forest on species richness on the local scales (in line with Liivamägi et al. 2014; Villemey et al. 2015; Toivonen et al. 2017) decreased with increasing scale. In contrast, seminatural grasslands were the most important habitat at larger scales, peaking at $20000 \mathrm{~m}$. Studies that have reported negative effects of semi-natural grasslands (Liivamägi et al. 2014) or no response (Krämer et al. 2012; Villemey et al. 2015), all used smaller spatial scales. Our results suggest that these findings may depend on the scale on which landscape variables was measured. Hence, it is important to also consider large spatial scales to fully understand the species distribution in a landscape. The large-scale influence of seminatural grasslands on species richness is clear when looking at the maps over species-rich sites and amount of semi-natural grasslands (Fig. 1, 3). The reason for the large scale of response to semi-natural grasslands may be due to the dynamics in the grasslands and surrounding habitats together with species specific habitat requirements. It has been shown for several butterfly species that 15-20 grassland patches are necessary for long term survival (Thomas 1994; Hanski et al. 1996; Thomas and Hanski 1997; Bergman and Kindvall 2004). This suggests that landscapes with a high amount of semi-natural grassland not only have a larger species pool but also increased probability to harbour specialized species with specific requirements. Also, the quality of surrounding habitats (e.g. forest clear-cuts, road verges) may be highly dynamic. If a part of the patches consists of dynamic patches like forest clearcuts - that support the grassland butterflies - the number of patches and landscape size that a species need for long term survival will probably increase as introducing habitat dynamics in a system will increase extinction probabilities (Ranius 2007). To reach the same level of persistence in the system, the total amount of patches then need to increase. However, in a similar system for Euphydryas aurinia, a butterfly using both open semi-natural grasslands and clearcuts, it was clear that the key factor for long term survival was the continued presence of the seminatural grasslands in the landscape (Wahlberg et al. 2002).

On the species level, some species showed a clear response to a wide range of scales, and others showed clear responses either at the local or landscape scales. The results are consistent with a number of other studies that have shown that related species respond to the same habitat factor at different scales (Roland and Taylor 1997; Gorresen et al. 2005; Westphal et al. 
2006; Paltto et al. 2010; Bergman et al. 2012). Several factors can affect the scale of response including niche breadth (Gehring and Swihart 2003), behavior (Van Dyck and Baguette 2005), body size (Holland et al. 2005) and species mobility (Ricketts et al. 2001, Jackson and Fahrig 2012). In the current study, wing length and larval development time seemed unrelated to the characteristic scale and only diet affected the scale of response significantly. Wing length is widely used as a proxy for butterfly dispersal ability, however in a large meta-analysis the predictive power was low (Sekar 2012), and our results may reflect this. Our hypothesis about a positive relationship between scales of response and a wider use of host plants (as there would be more suitable habitat available for those being generalist feeders) was only partly supported by data in that oligophagous species had larger scales of response than monophagous ones. In conflict with this was the significantly smaller scales of response among polyphagous species compared with monophagous. However, many grass feeding butterflies that is suggested to have low dispersal ability (Bink 1992) are in the polyphagous group which may partly explain the results. An explanation for the overall low effect of species traits in this study may also be that we measure the effect of different habitats that species may respond to for different reasons. For example, forest may act both as a resource with host plants but may also be used as shelter at the local scale as open areas may be exposed to windy conditions (Dover et al. 1997; Villemey et al. 2015). Finally, it is worth noting that the identification of a single peak scale of response in itself sometimes can be misleading, especially for species that do not display a clear peak defining the selected scale.

\section{Implications for conservation}

It is clear that the surrounding landscape is important for most butterfly species occurring in grasslands and that (i) species respond differently to land cover in the surrounding, and (ii) that the spatial scale where such an effect is manifested varies greatly among species. A proper appreciation of these spatial attributes of species seems essential for understanding the distribution of species, their response to changes (e.g. land use or global warming), to intervention (e.g. restoration), and to the effect of spatial planning (e.g. green infrastructure).
Another important finding is that forested land constitutes an important butterfly habitat, and that when the extent of that habitat is large, it might go from being an alternative or supplementary habitat for grassland butterflies to becoming their main habitat. Hence, further studies are needed to properly identify which habitats inside the forests are exploited.

Finally, a subset of the grassland species studied responded positively toward grasslands in the surrounding but not forest. They would be worthy of special attention, as they are likely candidates for the Red List if the acreage of semi-natural grassland will continue to decrease.

Acknowledgements KOB received funds from WWF Sweden (Innovativ naturvård, Project Number 500131); EÖ was funded by the Swedish Research Council Formas (Contract 942-2015-988). The NILS program is funded by the Swedish Environmental Protection Agency while the butterfly sampling is funded by the Swedish Board of Agriculture. Thanks to Erik Cronvall and other staff at NILS, the Department of Forest Resource Management, Swedish University of Agricultural Sciences, for providing us with data and data expertise.

Open Access This article is distributed under the terms of the Creative Commons Attribution 4.0 International License (http:// creativecommons.org/licenses/by/4.0/), which permits unrestricted use, distribution, and reproduction in any medium, provided you give appropriate credit to the original author(s) and the source, provide a link to the Creative Commons license, and indicate if changes were made.

\section{References}

Axelsson A-L, Östlund L (2001) Retrospective gap analysis in a Swedish boreal forest landscape using historical data. For Ecol Manag 147:109-122

Barnosky AD, Hadly EA, Bascompte J, Berlow EL, Brown JH, Fortelius M, Getz WM, Harte J, Hastings A, Marquet PA, Martinez ND, Mooers A, Roopnarine P, Vermeij G, Williams JW, Gillespie R, Kitzes J, Marshall C, Matzke N, Mindell DP, Revilla E, Smith AB (2012) Approaching a state shift in Earth's biosphere. Nature 486:52-58

Berg ̊̊, Ahrné K, Öckinger E, Svensson R, Söderström B (2011) Butterfly distribution and abundance is affected by variation in the Swedish forest-farmland landscape. Biol Conserv 144:2819-2831

Berg ̊̊, Bergman K-O, Wissman J, Żmihorski M, Öckinger E (2016) Power-line corridors as source habitat for butterflies in forest landscapes. Biol Conserv 201:320-326

Bergman K-O, Ask L, Askling J, Ignell H, Wahlman H, Milberg P (2008) Importance of boreal grasslands in Sweden for butterfly diversity and effects of local and landscape habitat factors. Biodivers Conserv 17:139-153 
Bergman K-O, Askling J, Ekberg O, Ignell H, Wahlman H, Milberg P (2004) Landscape effects on butterfly assemblages in an agricultural region. Ecography 27:619-628

Bergman K-O, Jansson N, Claesson K, Palmer MW, Milberg P (2012) How much and at what scale? Multiscale analyses as decision support for conservation of saproxylic oak beetles. For Ecol Manag 265:133-141

Bergman K-O, Kindvall O (2004) Population viability analysis of the butterfly Lopinga achine in a changing landscape in Sweden. Ecography 27:49-58

Bergstedt J, Axelsson A-L, Karlsson J, Lönander J, Törnqvist L, Milberg P (2017) Förändringar i Eklandskapet 1927 till 2013: i den första Riksskogstaxeringens fotspår. Sven Bot Tidskr 111:331-343

Bink FA (1992) Ecologische atlas van de dagvlinders van Noordwest-Europa. Schuyt

Blixt T, Bergman K-O, Milberg P, Westerberg L, Jonason D (2015) Clear-cuts in production forests: From matrix to neo-habitat for butterflies. Acta Oecol 69:71-77

Börschig C, Klein AM, von Wehrden H, Krauss J (2013) Traits of butterfly communities change from specialist to generalist characteristics with increasing land-use intensity. Basic Appl Ecol 14:547-554

Botham MS, Fernandez-Ploquin EC, Brereton T, Harrower CA, Roy DB, Heard MS (2015) Lepidoptera communities across an agricultural gradient: how important are habitat area and habitat diversity in supporting high diversity? J Insect Conserv 19:403-420

Broughton RK, Shore RF, Heard MS, Amy SR, Meek WR, Redhead JW, Turk A, Pywell RF (2014) Agri-environment scheme enhances small mammal diversity and abundance at the farm-scale. Agric Ecosyst Environ 192:122-129

Brückmann SV, Krauss J, Steffan-Dewenter I (2010) Butterfly and plant specialists suffer from reduced connectivity in fragmented landscapes. J Appl Ecol 47:799-809

Cousins SA, Auffret AG, Lindgren J, Tränk L (2015) Regionalscale land-cover change during the 20th century and its consequences for biodiversity. Ambio 44:17-27

Cronvall E (2015) Fältinstruktion för fjärilar, humlor, grova träd och lavar i ängs- och betesmarker år 2015. Sveriges lantbruksuniversitet (SLU) (In Swedish)

Davies KF, Margules CR, Lawrence JF (2000) Which traits of species predict population declines in experimental forest fragments? Ecology 81:1450-1461

Development Core Team R (2014) R: a language and environment for statistical computing. R Foundation for Statistical Computing, Vienna, Austria

Dover JW, Sparks TH, Greatorex-Davies JN (1997) The importance of shelter for butterflies in open landscapes. J Insect Conserv 1:89-97

Driscoll DA, Banks SC, Barton PS, Lindenmayer DB, Smith AL (2013) Conceptual domain of the matrix in fragmented landscapes. Trends Ecol Evol 28:605-613

Duflot R, Aviron S, Ernoult A, Fahrig L, Burel F (2015) Reconsidering the role of 'semi-natural habitat' in agricultural landscape biodiversity: a case study. Ecol Res 30:75-83

Dupré C, Ehrlén J (2002) Habitat configuration, species traits and plant distributions. J Ecol 90:796-805
Ekroos J, Heliölä J, Kuussaari M (2010) Homogenization of lepidopteran communities in intensively cultivated agricultural landscapes. J Appl Ecol 47:459-467

Eliasson CU (ed) (2005) Nationalnyckeln till Sveriges Flora och Fauna. Fjärilar: Dagfjärilar. Hesperiidae-Nymphalidae. SLU, Uppsala (In Swedish with English summary)

Environmental Protection Agency (2014) Svenska Marktäckedata. Stockholm (In Swedish)

ESRI (2012) ESRI, ArcMap 10.1. Redlands, CA, USA: Environmental Systems Research Institute; 2013

Evans MJ, Banks SC, Driscoll DA, Hicks AJ, Melbourne BA, Davies KF (2017) Short- and long- term effects of habitat fragmentation differ but are predicted by response to the matrix. Ecology 98:807-819

Ewers RM, Didham RK (2005) Confounding factors in the detection of species responses to habitat fragmentation. Biol Rev 81:117-142

Fahrig L (2003) Effects of habitat fragmentation on biodiversity. Annu Rev Ecol Evol Syst 34:487-515

Foley JA, DeFries R, Asner GP, Barford C, Bonan G, Carpenter SR, Chapin FS, Coe MT, Daily GC, Gibbs HK, Helkowski JH, Holloway T, Howard EA, Kucharik CJ, Monfreda C, Patz JA, Prentice IC, Ramankutty N, Snyder PK (2005) Global consequences of land use. Science 309:570-574

Franklin JF (1993) Preserving biodiversity: species, ecosystems, or landscapes? Ecol Appl 3:202-205

Gehring TM, Swihart RK (2003) Body size, niche breadth, and ecologically scaled responses to habitat fragmentation: mammalian predators in an agricultural landscape. Biol Conserv 109:283-295

Gorresen PM, Willig MR, Strauss RE (2005) Multivariate analysis of scale-dependent associations between bats and landscape structure. Ecol Appl 15:2126-2136

Green RE, Cornell SJ, Scharlemann JPW, Balmford A (2005) Farming and the fate of wild nature. Science 307:550-555

Halder I, Thierry M, Villemey A, Ouin A, Archaux F, Barbaro L, Balent G, Benot ML (2017) Trait-driven responses of grassland butterflies to habitat quality and matrix composition in mosaic agricultural landscapes. Insect Conserv Divers 10:64-77

Hanski I (1999) Metapopulation ecology. Oxford University Press, Oxford

Hanski I, Moilanen A, Gyllenberg M (1996) Minimum viable metapopulation size. Am Nat 147:527-541

Holland JD, Bert DG, Fahrig L (2004) Determining the spatial scale of species' response to habitat. Bioscience 54:227-233

Holland JD, Fahrig L, Cappuccino N (2005) Body size affects the spatial scale of habitat-beetle interactions. Oikos 110:101-108

Ibbe M, Milberg P, Tunér A, Bergman K-O (2011) History matters: impact of historical land use on butterfly diversity in clear-cuts in a boreal landscape. For Ecol Manag 261:1885-1891

Jackson HB, Fahrig L (2012) What size is a biologically relevant landscape? Landscape Ecol 27:929-941

Jonason D, Bergman K-O, Westerberg L, Milberg P (2016) Land-use history exerts long-term effects on the clear-cut flora in boreonemoral Sweden. Appl Veg Sci 19:634-643

Jonason D, Ibbe M, Milberg P, Tunér A, Westerberg L, Bergman K-O (2014) Vegetation in clear-cuts depends on 
previous land use: a century-old grassland legacy. Ecol Evol 4:4287-4295

Jonason D, Milberg P, Bergman K-O (2010) Monitoring of butterflies within a landscape context on south-eastern Sweden. J Nat Conserv 18:22-33

Kennedy CM, Marra PP, Fagan WF, Neel MC (2010) Landscape matrix and species traits mediate responses of Neotropical resident birds to forest fragmentation in Jamaica. Ecol Monogr 80:651-669

Komonen A, Grapputo A, Kaitala V, Kotiaho JS, Päivinen J (2004) The role of niche breadth, resource availability and range position on the life history of butterflies. Oikos 105:41-54

Krämer B, Poniatowski D, Fartmann T (2012) Effects of landscape and habitat quality on butterfly communities in prealpine calcareous grasslands. Biol Conserv 152:253-261

Krauss J, Bommarco R, Guardiola M, Heikkinen RK, Helm A, Kuussaari M, Lindborg R, Öckinger E, Pärtel M, Pino J, Pöyry J, Raatikainen KM, Sang A, Stefanescu C, Teder T, Zobel M, Steffan-Dewenter I (2010) Habitat fragmentation causes immediate and time-delayed biodiversity loss at different trophic levels. Ecol Lett 13:597-605

Kruess A, Tscharntke T (2002) Grazing intensity and the diversity of grasshoppers, butterflies, and trap-nesting bees and wasps. Conserv Biol 16:1570-1580

Kuussaari M, Heliölä J, Pöyry J, Saarinen K (2007) Contrasting trends of butterfly species preferring semi-natural grasslands, field margins and forest edges in northern Europe. J Insect Conserv 11:351-366

Lampinen J, Heikkinen RK, Manninen P, Ryttäri T, Kuussaari $M$ (2018) Importance of local habitat conditions and past and present habitat connectivity for the species richness of grassland plants and butterflies in power line clearings. Biodivers Conserv 27:217-233

Levins R (1969) Some demographic and genetic consequences of environmental heterogeneity for biological control. Bull Entomol Soc Am 15:237-240

Liivamägi A, Kuusemets V, Kaart T, Luig J, Diaz-Forero I (2014) Influence of habitat and landscape on butterfly diversity of semi-natural meadows within forest-dominated landscapes. J Insect Conserv 18:1137-1145

MacArthur RH, Wilson EO (1967) The theory of island biogeography. Princeton University Press, Princeton

Marini L, Fontana P, Battisti A, Gaston KJ (2009) Agricultural management, vegetation traits and landscape drive orthoptera and butterfly diversity in a grassland-forest mosaic: a multi-scale approach. Insect Conserv Divers 2:213-220

Milberg P, Bergman KO, Cronvall E, Eriksson ÅI, Glimskär A, Islamovic A, Jonason D, Löfqvist Z, Westerberg L (2016) Flower abundance and vegetation height as predictors for nectar-feeding insect occurrence in Swedish semi-natural grasslands. Agr Ecosyst Environ 230:47-54

Niklasson M, Granström A (2000) Numbers and sizes of fires: long-term spatially explicit fire history in a swedish boreal landscape. Ecology 81:1484-1499

Öckinger E, Bergman K-O, Franzén M, Kadlec T, Krauss J, Kuussaari M, Pöyry J, Smith HG, Steffan-Dewenter I, Bommarco R (2012a) The landscape matrix modifies the effect of habitat fragmentation in grassland butterflies. Landscape Ecol 27:121-131
Öckinger E, Lindborg R, Sjödin NE, Bommarco R (2012b) Landscape matrix modifies richness of plants and insects in grassland fragments. Ecography 35:259-267

Öckinger E, Schweiger O, Crist TO, Debinski DM, Krauss J, Kuussaari M, Petersen JD, Pöyry J, Settele J, Summerville KS, Bommarco R (2010) Life-history traits predict species responses to habitat area and isolation: a cross-continental synthesis. Ecol Lett 13:969-979

Öckinger E, Smith HG (2006) Landscape composition and habitat area affects butterfly species richness in semi-natural grasslands. Oecologia 149:526-534

Ouin A, Aviron S, Dover J, Burel F (2004) Complementation/supplementation of resources for butterflies in agricultural landscapes. Agric Ecosyst Environ 103:473-479

Paltto H, Thomasson I, Nordén B (2010) Multispecies and multiscale conservation planning: setting quantitative targets for red-listed lichens on ancient oaks. Conserv Biol 24:758-768

Pöyry J, Luoto M, Heikkinen RK, Kuussaari M, Saarinen K (2009) Species traits explain recent range shifts of Finnish butterflies. Global Chang Biol 15:732-743

Prevedello JA, Vieira MV (2010) Does the type of matrix matter? A quantitative review of the evidence. Biodivers Conserv 19:1205-1223

Prugh LR, Hodges KE, Sinclair ARE, Brashares JS (2008) Effect of habitat area and isolation on fragmented animal populations. Proc Natl Acad Sci USA 105:20770-20775

Ranius T (2007) Extinction risks in metapopulations of a beetle inhabiting hollow trees predicted from time series. Ecography 30:716-726

Ricketts TH (2001) The matrix matters: effective isolation in fragmented landscapes. Amer Nat 158:87-99

Ricketts TH, Daily GC, Ehrlich PR, Fay JP (2001) Countryside biogeography of moths in a fragmented landscape: biodiversity in native and agricultural habitats. Conserv Biol 15:378-388

Roland J, Taylor PD (1997) Insect parasitoid species respond to forest structure at different spatial scales. Nature 386:710-713

Sekar S (2012) A meta-analysis of the traits affecting dispersal ability in butterflies: can wingspan be used as a proxy? J Anim Ecol 81:174-184

Shreeve TG, Dennis RLH (2011) Landscape scale conservation: resources, behaviour, the matrix and opportunities. J Insect Conserv 15:179-188

Sjödin NE (2007) Pollinator behavioural responses to grazing intensity. Biodivers Conserv 16:2103-2121

Smith AC, Fahrig L, Francis CM (2011) Landscape size affects the relative importance of habitat amount, habitat fragmentation, and matrix quality on forest birds. Ecography 34:103-113

Ståhl G, Allard A, Esseen P-A, Glimskär A, Ringvall A, Svensson J, Sundquist S, Christensen P, Gallegos Torell Å, Högström M, Lagerqvist K, Marklund L, Nilsson B, Inghe O (2011) National Inventory of Landscapes in Sweden (NILS): scope, design, and experiences from establishing a multiscale biodiversity monitoring system. Environ Monit Assess 173:579-595

Steffan-Dewenter I, Tscharntke T (2000) Butterfly community structure in fragmented habitats. Ecol Lett 3:449-456 
Stoate C, Báldi A, Beja P, Boatman ND, Herzon I, van Doorn A, de Snoo GR, Rakosy L, Ramwell C (2009) Ecological impacts of early 21 st century agricultural change in Europe-a review. J Environ Manag 91:22-46

Swedish Board of Agriculture (2005) Ängs-och betesmarksinventeringen 2002-2004. Rapport. Jönköping (In Swedish with English summary) Swedish Environmental Protection Agency. 2006. Handbok för miljöövervakning. Dagaktiva fjärilar

Thomas CD (1994) Local extinctions, colonizations and distributions: habitat tracking by British butterflies. In: Leather SR, Watt AD, Mills NJ, et al. (eds) Individuals, populations and patterns in ecology. Intercept, pp 319-336

Thomas CD, Hanski I (1997) Butterfly metapopulations. In: Hanski I, Gilpin ME (eds) Metapopulation biology: ecology, genetics and evolution. Academic Press, San Diego, pp 359-386

Toivonen M, Peltonen A, Herzon I, Heliölä J, Leikola N, Kuussaari M (2017) High cover of forest increases the abundance of most grassland butterflies in boreal farmland. Insect Conserv Diver 10:321-330

Tscharntke T, Klein AM, Kruess A, Steffan-Dewenter I, Thies C (2005) Landscape perspectives on agricultural intensification and biodiversity- ecosystem service management. Ecol Lett 8:857-874

Van Dyck H, Baguette M (2005) Dispersal behaviour in fragmented landscapes: routine or special movements? Basic Appl Ecol 6:535-545

Van Halder I, Barbaro L, Jactel H (2011) Conserving butterflies in fragmented plantation forests: are edge and interior habitats equally important? J Insect Conserv 15:591-601

van Swaay C, van Strien AJ, Harpke A, Fontaine B, Stefanescu C, Roy D, Maes D, Kühn E, Õunap E, Regan E, Švitra G, Heliölä J, Settele J, Pettersson LB, Titeux N, Cornish N,
Leopold P, Julliard R, Verovnik R, Popov S, Collins S, Goloshchapova S, Roth T, Brereton T, Warren MS (2013) The European grassland butterfly indicator: 1990-2011. Technical Report, Luxembourg, EEA. https://doi.org/10. 2800/89760

van Swaay C, Warren M, Loïs G (2006) Biotope use and trends of European butterflies. J Insect Conserv 10:189-209

Viljur M-L, Teder T (2016) Butterflies take advantage of contemporary forestry: clear-cuts as temporary grasslands. For Ecol Manag 376:118-125

Viljur ML, Teder T (2018) Disperse or die: colonisation of transient open habitats in production forests is only weakly dispersal-limited in butterflies. Biol Conserv 218:32-40

Villemey A, van Halder I, Ouin A, Barbaro L, Chenot J, Tessier P, Calatayud F, Martin H, Roche P, Archaux F (2015) Mosaic of grasslands and woodlands is more effective than habitat connectivity to conserve butterflies in French farmland. Biol Conserv 191:206-215

Wahlberg N, Klemetti T, Hanski I (2002) Dynamic populations in a dynamic landscape: the metapopulation structure of the marsh fritillary butterfly. Ecography 25:224-232

WallisDeVries MF, Poschlod P, Willems JH (2002) Challenges for the conservation of calcareous grasslands in northwestern Europe: integrating the requirements of flora and fauna. Biol Conserv 104:256-273

Watling JI, Nowakowski J, Donnelly MA, Orrock JL (2011) Meta-analysis reveals the importance of matrix composition for animals in fragmented habitat. Global Ecol Biogeogr 20:209-217

Westphal C, Steffan-Dewenter I, Tscharntke T (2006) Bumblebees experience landscapes at different spatial scales: possible implications for coexistence. Oecologia 149:289-300 